\title{
The Death of Jim Loney, By James Welch • Irene Wanner
}

JAMES WELCH, whose previous credits include a poetry collection, Riding the Earthboy 40, and the well-received novel Winter in the Blood, has now published a second novel, The Death of Jim Loney. This title seems an unfortunate choice, rather like presenting someone a puzzle with its answer; the story which leads to the death, however, is subtle and complex.

Welch is an American Indian born and raised in Montana. About his first novel he said, "I have seen works written about Indians by whites . . but only an Indian knows who he is." In the new book, Jim Loney is half-Indian, half-white. He does not feel rooted in either race or tradition, and has no idea who he is.

The story is set in Harlem, a small Montana town. Loney is thirty-five and the last thing to have any impact in his life was being a star of the 1958 class B championship basketball team. His teammates are gone-one dead, another estranged because he has become a successful rancher using white man's methods, some are lost or forgotten, others work at odd jobs only long enough to pay the rent. Loney drifts in a constant drunk, dreaming and dazed, searching through his past for meaning.

Two women try to get him to make something of his life. His lover, Rhea, a teacher who escaped the high society pressures of Dallas, wants Loney to go to Seattle with her. Kate, Loney's older sister, has become a power in federal education programs and plans to take him to Washington, D.C. Loney neither resists nor agrees. However, his ties with the land, its history and the possibility of finding his own history by remaining there, are strong. He isolates himself from Kate and Rhea, physically and by drinking. A passive man, he finally gets his way simply by outwaiting them.

Interwoven with the conflict between Rhea and Kate is Loney's need to understand himself by discovering his past. His father, Ike, also a drunk, was abandoned by his wife. Loney does not remember his mother. Ike, in turn, abandoned his children to an "aunt," one of his lovers. She died and Loney is uncertain which memories of her are true, which are dreams. He was brought up in a church orphanage. Loney is afraid to sleep because of his dreams. He drinks cheap wine to dull the passing of his days and to give himself dreamless nights. Finally, there are no answers for Loney, not love, religion, friends, work or family. Only death.

The major strength of the novel is its narrative, a consistently flat and desolate tone which only occasionally reveals the lyrical talents of Welch as poet. The writing is sparse and controlled, supporting Loney's hopelessness in both language and events:

Harper \& Row. 179 pages. $\$ 8.95$. 
Loney turned to the dog. "You tell Amos that Jim Loney passed through town while he was dreaming. Don't tell him you saw me with a bottle and gun. That wouldn't do. Give him dreams. Tell him you saw me carrying a dog and that I was taking that dog to a higher ground. He will know.'

If there is any fault to the book, it would seem to be omission. The novel covers several months in less than 200 pages, with the result that days and weeks are passed over without comment. This is obviously Welch's intention. Much of Loney's life is empty and perhaps best left untold, but Welch's power as a writer makes one wish he had given the book more of a chance, that he had let it take off and fly like the dark bird of Jim Loney's dreams. 